\title{
Morbidity and school absence caused by asthma and wheezing illness
}

\author{
H R ANDERSON, P A BAILEY, J S COOPER, J C PALMER, AND S WEST \\ Department of Clinical Epidemiology and Social Medicine, St George's Hospital Medical School, London
}

SUMmARY A survey in the London Borough of Croydon was conducted among an entire school cohort, aged about 9 years, to describe the current morbidity from wheezing illness, its relation to social and family factors, and its effects on social and educational development. A postal screening questionnaire was sent to 5100 parents, and $11 \cdot 1 \%$ of the children were reported to have had wheezing illness over the previous 12 months. A sample of 284 parents were subsequently interviewed at home about their child's illness. School absence over the past year caused by wheezing illness was reported by $58 \%$; and in $12 \%$ of childrën this amounted to more than 30 school days. School absence was strongly associated with all other indicators of morbidity-short and long term. The proportion described as having 'asthma' rose from $22 \%$ in those with no absence, to $50 \%$ in those with more than 30 days absence. Compared with 92 randomly selected controls with no history of wheezing, wheezy children had more atopic conditions, recurrent headaches, and abdominal pains. School absence was associated with parental separation, non-manual occupation of the mother, more than three children in the household, poor maternal mental health, lack of access to a car, and renting of accommodation. The child's illness had substantial effects on the activities of the mother and the rest of the family, but not on the child's social and recreational activities. Children with over 6 weeks' school absence scored appreciably worse on a teacher's assessment of their social, psychological, and educational adjustment.

In the course of a 12 month period, about $10 \%$ of school age children are likely to experience symptoms of wheezing, and about $3 \%$ will be labelled as asthmatic. ${ }^{1}$ Wheezing illness is a major cause of chronic ill health in childhood ${ }^{2}$ but few population surveys have assessed its impact on family life or on the child's emotional, social, and educational development. ${ }^{3}$ Those which have done so conclude that if problems occur at all, they are mainly confined to a minority of severely affected children. 4567 Since the time of these studies, remarkable advances have occurred in the treatment of asthma that may now prevent severe episodes and long term disability by the regular administration of sodium cromoglycate, bronchodilators, and steroids by inhalation. Freedom from disability and life threatening attacks has become a realistic treatment goal. In spite of this, hospital admissions are increasing $^{8}$ and there is a widespread impression that wheezing illness remains a substantial primary care problem. ${ }^{9}$

School attendance is relatively easy to quantify, is part of every child's normal activity, and is regarded as important for normal development. We have therefore ised school absence as the principal indicator of disability caused by wheezing illness. The relation between school absence and other indicators of morbidity, the educational and social development of the child, and various characteristics of the child's family and social circumstances are examined.

\section{Methods}

Children with wheezing illness were identified by postal screening survey and the parents of a sample of these were subsequently interviewed at home about the illness and its medical care. The population screened consisted of children in the school class born between August 1969 and September 1970, attending all local authority and private schools in the London Borough of Croydon. With the assistance of the School Health Service, a short questionnaire was sent to the parents. The screening questions were: 'Has your child ever had asthma?' If No, 'Has he or she ever had an episode of wheeziness in the 
chest ?'. If the reply was 'Yes' to either question, the number of episodes over the past 12 months was recorded.

Replies were received from $87 \%$ of 4813 local authority and 295 private school children screened (total 5108). The sample for home interview of the parents was selected to include all of those with five or more episodes over the past 12 months (100), a $52 \%$ sample of those with fewer episodes (200), and 110 randomly selected non-wheezy children. Of this sample of $421,376(89 \%)$ were successfully interviewed. The shortfall was caused by change of address (15), inability to contact (12), refused (8), misclassification by screening questionnaire (9), and useless interview (1). The interviews took place over the 6-12 months after the screening survey, using one principal interviewer and two part time assistants.

The home questionnaire obtained information about morbidity from wheezing illness and other conditions, the effects of the illness on the family, related use of drugs and services, and socioeconomic and family factors. Morbidity over the past 12 months was assessed by wheeze symptom (with or without 'episodes'), nocturnal episodes, episodes severe enough to prevent the child speaking, days in bed, and restriction of activities around the home or at school. School absence was measured in terms of the reported number of days of absence, the number of spells, and the length of the longest spell.

Details of social, club, and sporting activities were obtained. Educational attainment was measured using school records of the Neale and Young reading tests. School absence records were obtained but these did not specify the type of illness. Schools also provided the results of a teacher completed 'checklist' that is designed to detect problems in the areas of: speech and communication; perceptual, motor, emotional, and social development; and response to learning situations (personal communication, Croydon Education Department).

Socioeconomic factors obtained were: parental separation or absence of parental figures; the parents' birthplace, education, occupation, and hours of employment; the mother's physical and mental health, marital status, and ethnic group (by observation); tenure of accommodation; crowding; the number and ages of other children in the household; and access to a car and telephone.

Because different sampling fractions were used, an appropriate adjustment was made for estimating the prevalence of various morbidity factors in the whole population of wheezy children. Associations and trends were tested for statistical significance using the $\chi^{2}$ test. To examine the effect of one factor on school absence while controlling for another, two factor logistic models were fitted. ${ }^{10}$

\section{Results}

At the screening survey, $18 \cdot 2 \%$ of children were reported to have had episodes of wheezing or asthma at any time in the past-the proportion was higher in boys $(21.1 \%)$ than in girls $(15.3 \%)$. Over the previous twelve months, the prevalence was $11.1 \%$, and while this was higher in boys $(12.7 \%)$ than in girls $(9.6 \%)$, the proportion reporting 5 or more episodes was the same for each sex $(2 \cdot 3 \%)$. There were no differences in prevalence between local authority and private schools.

The validity of the screening questionnaire was tested by the subsequent home interview. Of the 292 children who were screened positive, 7 did not have wheeze and two of these had been confused with other siblings. Of 94 screened as negative, two were found to have wheezing illness; one had been confused with another sibling and the other had developed wheeze since the screening survey.

At the time of the home interview the age of the children was mean (SD) $8.9(0.47)$ years (range 7.9-11.0 years). School absence in the past year because of wheezing illness was reported by $58 \%$ of children (Table 1) and $12 \%$ of children had lost more than 30 days (6 school weeks). Table 1 also shows the number of spells of absence and the duration of the longest single spell of absence: these are highly

Table 1 Nine year old Croydon children: school absence in the past year because of wheezing illness*

\begin{tabular}{|c|c|c|c|c|}
\hline & & $\begin{array}{l}\text { Total } \\
n=284 \\
\% \dagger\end{array}$ & $\begin{array}{l}\text { Boys } \\
n=163 \\
\%\end{array}$ & $\begin{array}{l}\text { Girls } \\
n=121 \\
\%\end{array}$ \\
\hline $\begin{array}{l}\text { Absence from school } \\
\text { (days) }\end{array}$ & $\begin{array}{l}0 \\
1-10 \\
11-30 \\
31+\end{array}$ & $\begin{array}{r}36 \\
33 \\
17 \\
12 \\
2\end{array}$ & $\begin{array}{r}31 \\
33 \\
17 \\
15 \\
4\end{array}$ & $\begin{array}{r}36 \\
34 \\
17 \\
13 \\
1\end{array}$ \\
\hline No information & $\begin{array}{l}0 \\
1 \\
2-4 \\
5+\end{array}$ & $\begin{array}{r}36 \\
10 \\
33 \\
19 \\
2\end{array}$ & $\begin{array}{r}31 \\
12 \\
33 \\
21 \\
3\end{array}$ & $\begin{array}{r}36 \\
5 \\
32 \\
26 \\
2\end{array}$ \\
\hline $\begin{array}{l}\text { Longest period away } \\
\text { from school (days) }\end{array}$ & $\begin{array}{l}0 \\
1-2 \\
3-5 \\
6-10 \\
11+\end{array}$ & $\begin{array}{r}36 \\
8 \\
39 \\
9 \\
7 \\
1\end{array}$ & $\begin{array}{l}31 \\
11 \\
38 \\
11 \\
7 \\
1\end{array}$ & $\begin{array}{r}36 \\
7 \\
40 \\
8 \\
9 \\
0\end{array}$ \\
\hline
\end{tabular}

*Boys $v$ girls, not significant for each indicator of absence.

+Percentage prevalence adjusted for sampling fraction. This provides an estimate for the whole population of wheezy children.

Days school absence $(1-10,11+)$ versus:

No of absences $\chi^{2} 59.1, \mathrm{P}<0.001 ; \chi^{2}$ (trend) $57.8, \mathrm{P}<0.001$

Longest period $\gamma_{-2}^{?} 69 \cdot 2, \mathrm{P}<0.001 ; \chi^{2}$ (trend) $61 \cdot 2, \mathrm{P}<0.001$ 
correlated with the number of days of absence. Boys exceeded girls by $1 \cdot 4: 1$ in the sample, but within each sex the pattern of school absence because of wheezing was remarkably similar.

Onset of symptoms before the age of two years was reported by $54 \%$ of children with $11+$ days absence over the past year, $46 \%$ with lesser absence, and $44 \%$ with no absence. This trend was not statistically significant.

It was not possible to obtain school absence records specific for wheezing illness, or that corresponded precisely to the 12 month recall period used at interview. Records of absence for all reasons covering the last 3 complete school terms before interview, correlated significantly, however, with parental reports of absence for wheezing over the 12 months before interview.

The adjusted percentages reporting symptoms and disability because of wheezing illness are shown in Tables 2 and 3. At the time of the interview-which took place up to a year after the screening survey- $80 \%$ were reported to have had 'episodes' of wheeze in the past 12 months, and a further $8 \%$ were reported to have had wheeze symptoms of a non-episodic nature only. The remaining 29 children $(10 \%)$ had not wheezed over the past 12 months and

Table 2 Interval since the last wheeze symptom, nocturnal episode, or severe episode by the number of days absent from school because of wheezing*

\begin{tabular}{|c|c|c|c|c|c|c|c|}
\hline & \multicolumn{5}{|c|}{ School absence in past year (days) } & \multicolumn{2}{|c|}{ Significance } \\
\hline & & $\begin{array}{l}\text { Total } \\
n=284 \\
\%+\end{array}$ & $\begin{array}{l}\text { None }(A) \\
n=67 \\
\%\end{array}$ & $\begin{array}{l}1-10(B) \\
n=92 \\
\%\end{array}$ & $\begin{array}{l}11+(C) \\
n=89 \\
\%\end{array}$ & $\begin{array}{l}A \times B \times C \\
P \text { value }\end{array}$ & $\begin{array}{l}\text { Trend } \\
P \text { value }\end{array}$ \\
\hline $\begin{array}{l}\text { Episodes of wheeze within } \\
\text { the past: }\end{array}$ & $\begin{array}{l}2 \text { weeks } \\
1 \text { month } \\
6 \text { months } \\
12 \text { months }\end{array}$ & $\begin{array}{l}15 \\
22 \\
63 \\
80\end{array}$ & $\begin{array}{l}12 \\
16 \\
48 \\
63\end{array}$ & $\begin{array}{l}18 \\
25 \\
76 \\
96\end{array}$ & $\begin{array}{l}28 \\
39 \\
89 \\
99\end{array}$ & $\begin{array}{l}<0.05 \\
<0.01 \\
<0.001\end{array}$ & $\begin{array}{l}<0.05 \\
<0.01 \\
<0.001\end{array}$ \\
\hline $\begin{array}{l}\text { All wheezing whether } \\
\text { episodic or not } \\
\text { within the past: }\end{array}$ & $\begin{array}{l}2 \text { weeks } \\
1 \text { month } \\
6 \text { months } \\
12 \text { months }\end{array}$ & $\begin{array}{l}24 \\
32 \\
74 \\
88\end{array}$ & $\begin{array}{r}15 \\
18 \\
72 \\
100\end{array}$ & $\begin{array}{r}28 \\
38 \\
86 \\
100\end{array}$ & $\begin{array}{r}45 \\
57 \\
93 \\
100\end{array}$ & $\begin{array}{l}<0.001 \\
<0.001 \\
<0.001\end{array}$ & $\begin{array}{l}<0.001 \\
<0.001 \\
<0.001\end{array}$ \\
\hline $\begin{array}{l}\text { Woken at night } \\
\text { within the past: }\end{array}$ & $\begin{array}{l}2 \text { weeks } \\
1 \text { month } \\
6 \text { months } \\
12 \text { months }\end{array}$ & $\begin{array}{r}9 \\
11 \\
32 \\
40\end{array}$ & $\begin{array}{r}3 \\
3 \\
12 \\
19\end{array}$ & $\begin{array}{l}11 \\
13 \\
42 \\
55\end{array}$ & $\begin{array}{l}20 \\
28 \\
60 \\
67\end{array}$ & $\begin{array}{l}<0.01 \\
<0.001 \\
<0.001 \\
<0.001\end{array}$ & $\begin{array}{l}<0.001 \\
<0.001 \\
<0.001 \\
<0.001\end{array}$ \\
\hline $\begin{array}{l}\text { At least one severe } \\
\text { episode (affecting } \\
\text { speech) in the past: }\end{array}$ & $\begin{array}{l}2 \text { weeks } \\
1 \text { month } \\
6 \text { months } \\
12 \text { months }\end{array}$ & $\begin{array}{r}2 \\
4 \\
10 \\
13\end{array}$ & $\begin{array}{l}0 \\
1 \\
3 \\
5\end{array}$ & $\begin{array}{r}3 \\
5 \\
8 \\
11\end{array}$ & $\begin{array}{r}4 \\
8 \\
22 \\
28\end{array}$ & $\begin{array}{l}<0.001 \\
<0.001\end{array}$ & $\begin{array}{l}<0.001 \\
<0.001\end{array}$ \\
\hline
\end{tabular}

* 29 children with no symptoms in the past 12 months are excluded from the school absence analysis.

†Percentage prevalence adjusted for sampling fraction. Includes 7 subjects with no information on school absence.

Table 3 Disability because of wheezing illness, and its association with the number of days absent from school

\begin{tabular}{|c|c|c|c|c|c|c|c|}
\hline & & \multicolumn{4}{|c|}{ School absence in past year (days) } & \multicolumn{2}{|c|}{ Significance } \\
\hline & & $\begin{array}{l}\text { Total } \\
n=284 \\
\% *\end{array}$ & $\begin{array}{l}\text { None }(A) \\
n=94 \\
\%\end{array}$ & $\begin{array}{l}1-10(B) \\
n=94 \\
\%\end{array}$ & $\begin{array}{l}11+(C) \\
n=89 \\
\%\end{array}$ & $\begin{array}{l}A \times B \times C \\
P \text { value }\end{array}$ & $\begin{array}{l}\text { Trend } \\
P \text { value }\end{array}$ \\
\hline $\begin{array}{l}\text { Activities around the home } \\
\text { restricted in the past: }\end{array}$ & $\begin{array}{l}2 \text { weeks } \\
1 \text { month } \\
6 \text { months } \\
12 \text { months }\end{array}$ & $\begin{array}{r}6 \\
13 \\
27 \\
29\end{array}$ & $\begin{array}{r}2 \\
6 \\
11 \\
14\end{array}$ & $\begin{array}{r}7 \\
12 \\
30 \\
33\end{array}$ & $\begin{array}{l}16 \\
28 \\
51 \\
52\end{array}$ & $\begin{array}{l}<0.01 \\
<0.001 \\
<0.001 \\
<0.001\end{array}$ & $\begin{array}{l}<0.001 \\
<0.001 \\
<0.001 \\
<0.001\end{array}$ \\
\hline $\begin{array}{l}\text { Days in bed over } \\
\text { the past year: }\end{array}$ & $\begin{array}{l}1-5 \\
6-10 \\
11+\end{array}$ & $\begin{array}{r}19 \\
10 \\
5\end{array}$ & $\begin{array}{l}2 \\
1 \\
0\end{array}$ & $\begin{array}{r}28 \\
6 \\
1\end{array}$ & $\begin{array}{l}27 \\
25 \\
21\end{array}$ & $<0.001$ & $<0.001$ \\
\hline $\begin{array}{l}\text { Overall effect on } \\
\text { everyday activities } \\
\text { over the past year: }\end{array}$ & $\begin{array}{l}\text { None } \\
\text { A little } \\
\text { A lot }\end{array}$ & $\begin{array}{c}39 \\
51 \\
10\end{array}$ & $\begin{array}{c}72 \\
27 \\
0\end{array}$ & $\begin{array}{r}28 \\
71 \\
1\end{array}$ & $\begin{array}{r}3 \\
63 \\
33\end{array}$ & $<0.001$ & $<0.001$ \\
\hline $\begin{array}{l}\text { Limitation of games or } \\
\text { physical education over } \\
\text { the past year }\end{array}$ & & 24 & 9 & 23 & 52 & $<0.001$ & $<0.001$ \\
\hline
\end{tabular}

*Percentage prevalence adjusted for sampling fraction. 
for this reason are excluded from the analysis of symptoms and school absence in Table 2. They are, however, included in subsequent analyses since the factors examined could have been affected by the threat of symptoms as well as by their presence. Over the previous year, $40 \%$ had experienced nocturnal episodes and $13 \%$ had experienced episodes severe enough to interfere with speaking: only a small proportion ( $2 \%$ ) had experienced such episodes on 5 or more occasions. Activities around the home were affected in $29 \%$, and $34 \%$ had spent at least one day in bed. In response to a question about the overall effect of the illness on activities over the past year, $51 \%$ of parents replied 'a little' and $10 \%$ replied 'a lot'. All these indicators of morbidity were strongly associated with the number of days school absence over the previous year (Tables 2 and 3).

At the screening survey, $27 \%$ of children reported to have had wheezing illness were described as having 'asthma'. The asthma 'label' was significantly associated with severity-rising from $22 \%$ in those with no school absence to $50 \%$ in those with more than 30 days absence ( $\chi^{2}$ trend, $\mathbf{P}<0.001$ ).

Compared with controls, children with wheezing illness were more likely over the previous year to have experienced eczema $(1.5 \mathrm{x})$, allergic nose problems $(4 \cdot 1 \mathrm{x})$, frequent headaches $(1 \cdot 7 \mathrm{x})$, and frequent episodes of abdominal pain $(1.7 \mathrm{x})$ (Table 4). With the exception of eczema, all these conditions were strongly associated with the number of days of school absence due to wheezing illness.

Some effects of the child's illness on the rest of the family are shown in Table 5. The mother's activities were affected in $42 \%$; and this was described as 'a lot' by $7 \%$. Choice of holiday was affected in $11 \%$, household arrangements in $13 \%$, special arrangements of the child's bedroom had been necessary in $29 \%$, and $20 \%$ had got rid of a pet. Twenty nine percent of mothers reported that 'special allowances' were made for the child because of his or her illness. All these effects were strongly associated with the number of days school absence.

There was little evidence that the illness interfered with social activities. Overall, wheezy children were just as likely to belong to clubs $(62 \%)$ as were controls $(60 \%)$, and this similarity was observed across the individual types of clubs (cubs, brownies, boys' brigade, sports, dancing). Swimming was reported equally by wheezy children $(78 \%)$ and controls $(79 \%)$, and there was no difference in the proportion receiving special lessons (for example,

Table 4 Associations between school absence because of wheezing illness and the occurrence over the past year of eczema, hayfever, abdominal pain, and headache

\begin{tabular}{|c|c|c|c|c|c|c|c|}
\hline & \multicolumn{4}{|c|}{ School absence (days) } & \multicolumn{2}{|c|}{ Significance } & \multirow[b]{2}{*}{$\begin{array}{l}\text { Cintrols } \\
n=92 \\
\%\end{array}$} \\
\hline & $\begin{array}{l}\text { Total } \\
n=284 \\
\% *\end{array}$ & $\begin{array}{l}\text { None }(A) \\
n=94 \\
\%\end{array}$ & $\begin{array}{l}1-10(B) \\
n=94 \\
\%\end{array}$ & $\begin{array}{l}11+(C) \\
n=89 \\
\%\end{array}$ & $\begin{array}{l}A \times B \times C \\
P \text { value }\end{array}$ & $\begin{array}{l}\text { Trend } \\
P \text { value }\end{array}$ & \\
\hline $\begin{array}{l}\text { Eczema } \\
\text { Allergic nose problems } \dagger \\
\text { Abdominal pain }(5+\text { episodes) } \\
\text { Headaches }(5+\text { episodes })\end{array}$ & $\begin{array}{l}15 \\
33 \\
27 \\
40\end{array}$ & $\begin{array}{l}12 \\
29 \\
19 \\
33\end{array}$ & $\begin{array}{l}18 \\
34 \\
21 \\
37\end{array}$ & $\begin{array}{l}20 \\
44 \\
43 \\
49\end{array}$ & $\begin{array}{l}\text { NS } \\
\text { NS } \\
<0 \cdot 001 \\
\text { NS }\end{array}$ & $\begin{array}{l}\text { NS } \\
<0.05 \\
<0.001 \\
<0.05\end{array}$ & $\begin{array}{r}10 \\
8 \\
16 \\
23\end{array}$ \\
\hline
\end{tabular}

* Percentage prevalence adjusted for sampling fraction.

†Sneezing and nasal stuffiness attributed to allergic factors such as house dust, pollens, animals etc.

NS $=$ not significant.

Table 5 Effects of the child's wheezing illness on the family, by number of days school absence

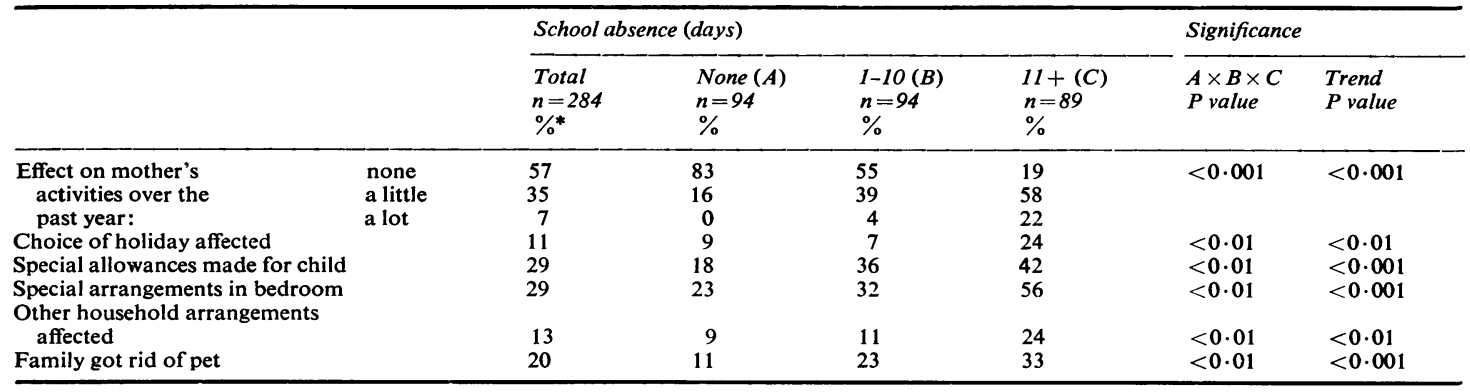

* Percentage prevalence adjusted for sampling fraction. 
music). Within the group of wheezy children, those with more school absence were less likely to belong to sports or dance clubs, or to have hobbies or favoured activities of a physically active nature, but none of these trends were statistically significant. There was no association between swimming and days of school absence.

The results of the Neale and Young reading tests are shown in Table 6. There was no statistical significance between reading age and days of school absence. Those with more than 30 days absence had the lowest mean reading age, but when compared with controls this difference fell short of statistical significance for the Young test, and was not significant for the Neale test.

The results of the 'check list' assessment by the teacher are shown in Table 7 as the percentage of children scoring the maximum overall, and for each

Table 6 Reading age, hy days of school absence. (Data shown are number $(n)$, mean reading age minus chronological age $(\bar{x})$, and the standard error of the mean (SEM)). No significant association shown between categories of absence, or between wheezy children and controls

\begin{tabular}{|c|c|c|c|}
\hline \multicolumn{2}{|c|}{ Days of school lost } & Neale test & Young test \\
\hline \multicolumn{4}{|c|}{ Children with wheezing illness } \\
\hline None & $\begin{array}{l}\mathrm{n} \\
\overline{\mathbf{x}}(\mathrm{SEM})\end{array}$ & $\begin{array}{l}78 \\
0.45(0.07)\end{array}$ & ${ }^{76} 0.03(0.13)$ \\
\hline $1-10$ & $\begin{array}{l}\mathbf{n} \\
\overline{\mathbf{x}}(\mathrm{SEM})\end{array}$ & $\stackrel{76}{0.50(0.07)}$ & $\stackrel{80}{0 \cdot 11(0 \cdot 12)}$ \\
\hline $11-29$ & $\begin{array}{l}\mathbf{n} \\
\overline{\mathbf{x}}(\mathrm{SEM})\end{array}$ & $\stackrel{40}{0.59}(0 \cdot 13)$ & $\begin{array}{l}41 \\
-0.02(0.17)\end{array}$ \\
\hline $30+$ & $\begin{array}{l}n \\
\overline{\mathbf{x}}(\mathrm{SEM})\end{array}$ & $\begin{array}{l}31 \\
0.38(0.14)\end{array}$ & $\begin{array}{l}32 \\
-0.25(0.20)\end{array}$ \\
\hline Controls & $\begin{array}{l}\mathrm{n} \\
\overline{\mathbf{x}}(\mathrm{SEM})\end{array}$ & $\begin{array}{l}68 \\
0.59(0.06)\end{array}$ & $\begin{array}{l}74 \\
0 \cdot 18(0 \cdot 12)\end{array}$ \\
\hline
\end{tabular}

separate subscale. Among children with more than 10 days school loss, the proportion scoring maximum for the overall score was just over half of that observed for children with lesser absence. The 'response to learning situations' was the only subscale to show a statistically significant trend with school absence. When wheezy children who had lost more than 30 days* school were compared with nonwheezy controls, they were found to have considerably lower scores overall, and for the 'speech/ communication' and 'emotional/social' subscales.

Among the wheezy children, 6 of the 32 socioeconomic indicators used were found to be associated with increased school absence (Table 8). These were: absence of one or both natural parents from the household, renting of accommodation, more than 3 children in the household, lack of access to a car, a history of treatment for nerves or depression in the mother, and non-manual occupation of the mother (present or last occupation). Factors not showing a significant statistical association with absence are listed in the footnote to Table 8.

Some of these socioeconomic factors were interrelated and those pairs of factors that were significantly associated with each other are shown in Table 9. Tenure of accommodation stands out by being associated with all the others. A two factor logistic analysis was carried out to examine the effect of each factor on school absence, after controlling for the other. This type of analysis was used because school absence was recorded in categories, not as a continuous variable. The results are summarised in Table 9. The effect of tenure was independent of that of every other factor. The presence of more than three children in the household maintained its significant effect after controlling for accommodation, tenure, and access to a car. The effect of mother's occupation was independent of that of tenure.

A number of socioeconomic and family factors

Table 7 Percentage of children with maximum scores on teachers' 'check-list', by days of school absence

\begin{tabular}{|c|c|c|c|c|c|}
\hline Days of school lost & $\begin{array}{l}\text { Speech/ } \\
\text { communication } \\
\text { No }(\%)\end{array}$ & $\begin{array}{l}\text { Perceptual/motor } \\
\text { No }(\%)\end{array}$ & $\begin{array}{l}\text { Emotional/social } \\
\text { No }(\%)\end{array}$ & $\begin{array}{l}\text { Response to } \\
\text { learning situations } \\
\text { No }(\%)\end{array}$ & $\begin{array}{l}\text { Total } \\
\text { No }(\%)\end{array}$ \\
\hline $\begin{array}{l}\text { Children with whee } \\
\text { None }(n=71) \\
1-10(n=72) \\
11-29(n=33) \\
30+(n=27) \\
\chi_{P}^{2} \text { trend } \\
P\end{array}$ & $\begin{array}{l}\text { illness } \\
64(90) \\
64(89) \\
31(94) \\
23(85) \\
0.09 \\
\text { NS }\end{array}$ & $\begin{array}{l}68(96) \\
65(90) \\
32(97) \\
25(93) \\
0 \cdot 08 \\
\text { NS }\end{array}$ & $\begin{array}{l}47(66) \\
55(76) \\
21(64) \\
17(63) \\
0 \cdot 2 \\
\text { NS }\end{array}$ & $\begin{array}{l}59(83) \\
63(88) \\
18(55) \\
19(70) \\
6 \cdot 74 \\
<0.01\end{array}$ & $\begin{array}{l}44(62) \\
48(67) \\
13(39) \\
10(37) \\
7.8 \\
<0.01\end{array}$ \\
\hline $\begin{array}{l}\text { Controls }(\mathrm{n}=66) \\
\chi^{2} v 30+\text { days } \\
P\end{array}$ & $\begin{aligned} & 64(97) \\
& 4.41 \\
< & 0.05\end{aligned}$ & $\begin{array}{l}62(94) \\
0.06 \\
\text { NS }\end{array}$ & $\begin{aligned} & 59(89) \\
& 8.96 \\
&< 0.01\end{aligned}$ & $\begin{array}{l}57(86) \\
3 \cdot 28 \\
\text { NS }\end{array}$ & $\begin{aligned} & 47(71) \\
& 9.43 \\
&< 0.01\end{aligned}$ \\
\hline
\end{tabular}

NS = not significant. 
Table 8 Socioeconomic and family factors found to be significantly associated with school absence, or which distinguished the more severe group $(11+$ days absence) from controls*

\begin{tabular}{|c|c|c|c|c|c|}
\hline & \multicolumn{3}{|c|}{ School absence in past year (days) } & \multicolumn{2}{|l|}{ Significance } \\
\hline & $\begin{array}{l}\text { Controls } \\
n=92 \\
\text { No }(\%)\end{array}$ & $\begin{array}{l}0-10 \\
n=184 \\
N o(\%)\end{array}$ & $\begin{array}{l}11+ \\
n=89 \\
\text { No }(\%)\end{array}$ & $\begin{array}{l}\text { Controls } v \\
11+\text { days } \\
P \text { value }\end{array}$ & $\begin{array}{l}0-10 v \\
11+\text { days } \\
\text { P value }\end{array}$ \\
\hline $\begin{array}{l}\text { Both natural parents in household } \\
\text { More than } 3 \text { children in household } \\
\text { Owner-occupiers } \\
\text { Ownership or use of car } \\
\text { Mother's occupation non-manual } \\
\text { Mother treated for nerves or depression } \\
\text { Mother works full time } \\
\text { Mother receiving supplementary benefit } \\
\text { Father born in UK }\end{array}$ & $\begin{array}{l}75(81) \\
17(18) \\
54(59) \\
72(78) \\
52 / 87(60) \\
31 / 90(34) \\
28 / 91(31) \\
3(3) \\
75 / 89(84)\end{array}$ & $\begin{array}{l}160(85) \\
19(10) \\
128(68) \\
154(82) \\
110 / 179(61) \\
72 / 182(40) \\
75 / 183(41) \\
14(7) \\
139 / 182(76)\end{array}$ & $\begin{array}{l}65(73) \\
23(26) \\
45(51) \\
61(69) \\
64 / 84(76) \\
46 / 87(53) \\
42 / 88(48) \\
10(11) \\
61 / 86(71)\end{array}$ & $\begin{array}{l}\text { NS } \\
\text { NS } \\
\text { NS } \\
\text { NS } \\
<0.05 \\
<0.05 \\
<0.01 \\
<0.05 \\
<0.05\end{array}$ & $\begin{array}{l}<0.01 \\
<0.001 \\
<0.01 \\
<0.01 \\
<0.05 \\
<0.05 \\
\text { NS } \\
\text { NS } \\
\text { NS }\end{array}$ \\
\hline
\end{tabular}

* No associations were observed with: absence of parental figures; mother's age, place of birth, ethnic group, disability or long standing illness, education, qualifications, or employment status; father's education, qualifications, employment status, hours of work, or social class; type of accommodation, time at present address, children under 5 , use of telephone; child's sex, or position in the family.

NS = not significant.

Table 9 Pairs of factors that were associated with increased school absence, and with each other. Analysis of the effects of each factor on school absence $(11+$ days) after controlling for the effects of the other

\begin{tabular}{|c|c|c|c|}
\hline Factor $A$ & Factor $B$ & $\begin{array}{l}\text { Effect of } A \\
\text { controlling for } B \\
P \text { value }\end{array}$ & $\begin{array}{l}\text { Effect of } B \\
\text { controlling for } A \\
P \text { value }\end{array}$ \\
\hline $\begin{array}{l}\text { Parental separation } \\
\text { Parental separation } \\
\text { Parental separation } \\
>3 \text { children in } \\
\text { household } \\
>3 \text { children in } \\
\text { household* } \\
\text { Mother's mental } \\
\text { health } \\
\text { Mother's mental } \\
\text { health } \\
\text { Mother's } \\
\text { occupation } \\
\text { Car ownership }\end{array}$ & $\begin{array}{l}\text { Mother's mental } \\
\text { health } \\
\text { Tenure } \\
\text { Car ownership } \\
\text { Tenure }\end{array}$ & $\begin{array}{l}\text { NS } \\
\text { NS } \\
\text { NS } \\
<0.01 \\
<0.001 \\
\text { NS }\end{array}$ & $\begin{array}{l}<0.05 \\
<0.05 \\
<0.05 \\
<0.001 \\
<0.05 \\
<0.05\end{array}$ \\
\hline
\end{tabular}

*A significant interaction was also observed.

NS = not significant

were also found to distinguish controls from wheezy children with more than 10 days absence (Table 8). Wheezy children were more likely to have a mother with a non-manual occupation, who had been treated for nerves or depression, who worked full time, or was receiving supplementary benefit; they were less likely to have a father who had been born in the UK.

\section{Discussion}

The screening questionnaire was designed to identify all children with current wheezing, and its sensitivity in this respect was validated by the subsequent home interview. Since there was a good response and since all schools (whether from the private or public sector) were included, the estimates of morbidity obtained provide a good indication of the burden of wheezing illness in children of this age. This method of selection, by encompassing the whole range of severity, provided a good opportunity to examine factors associated with severity, as well as those that may distinguish wheezy from non-wheezy children.

The substantial proportion of children with severe wheezing illness who were not regarded by the parents as having 'asthma' emphasises the importance of using a screening questionnaire based on symptomatic rather than disease label criteria. In addition, as the subsequent home interview showed, it is important not to confine questions to 'episodes' of wheeze but to include questions about wheeze of a non-episodic nature.

Describing the morbidity caused by wheezing illness presents considerable difficulties. A widely accepted definition concentrates on the physiological criterion of variable obstruction to airflow, ${ }^{11}$ but this has not so far been satisfactorily translated into a practical epidemiological method. The three dimensions of morbidity adopted in this survey were symptoms, disability (interference with normal activities), and handicap (social and developmental consequences). ${ }^{12}$ We concentrated particularly on school absence as an indicator of disability since school attendance is a normal activity for all children, is considered to be necessary for social and educational development, and may be expressed quantitatively. Because schools do not record the reason for absence, we were not, however, able to validate the parental reports using an independent assessment. This aspect requires further research. School absence because of asthma is the net outcome 
of interactions between aetiological, treatment, and illness behavioural factors operating in unknown proportions. Nevertheless, the results suggest that school absence may be a useful indicator of the severity of disease since it was strongly associated with both short and long term morbidity indicators, and with associated atopic conditions. It may also be argued that the more traditional indicators, such as the frequency of attacks, are no less subject to treatment and illness behavioural influences.

Considering the complexity of factors that may influence school absence, it was surprising that only 6 of 32 social and family factors examined showed a statistically significant association with the degree of school absence. The lack of an association with father's social class does not support the finding of Dawson et al.$^{13}$ that severe asthma is more frequent in manual social classes. The strong association with rented accommodation suggests, however, that social factors may still be important, but that these are not satisfactorily indicated by the traditional social class analysis based on occupational grouping. Other studies, most recently that of mortality in the 1971 Census cohort, have also indicated the importance of accommodation tenure as a social indicator. ${ }^{14}$

Absence of a natural parent in the household is probably indicative of family stress, and its association with increased school absence confirms the finding of McNicol et al. ${ }^{6}$ in Melbourne. We have also confirmed these workers' finding that poor emotional health in the mother is more likely among more severely affected children. The explanation for these associations is a matter for speculation and cannot be explored adequately using the existing data. Stress may be important as an aetiological factor, or be associated with differences in treatment or illness behaviour. The present study found that poor maternal mental health was associated with less adequate treatment of the child ${ }^{15}$ which suggests that some effects may have been mediated through the treatment factor.

Unlike some previous surveys, severity was not found to be related to the sex of the child, position of the child in the family, or age at onset of symptoms. Severity was, as observed in most other surveys, associated with eczema and allergic nose problems. The less well known associations with headaches and abdominal pain described by Peckham and Butler ${ }^{7}$ were also shown.

When the most severe third of wheezy children were compared with the controls, few associations with social or family factors were observed. Four of the five observed associations involved the mother and could be interpreted as indicating stress, corresponding to the observation made by Davies ${ }^{16}$ in a general practice population. The association with father's place of birth was hard to reconcile with the lack of association with the mother's place of birth, or her ethnicity. The lack of an association with the social class of the father confirms the finding of Peckham and Butler. ${ }^{7}$

Previous population studies of the emotional and social adjustment of asthmatic children have usually concluded that problems occur only in a minority of severely affected children.4567 Our findings are different in that all groups of wheezy children, irrespective of severity, scored lower than controls on the teachers' assessment of their emotional and social state. This is more consistent with the theory that all wheezy children tend toward emotional/social abnormality rather than that this reflects the severity of the illness. Considering the simplicity of the assessment, these findings need confirmation. There was little evidence of social handicap in terms of club membership and other activities, and this corresponds to the findings of Dawson et al..$^{13}$ Swimming was equally common among the controls and all severity groups of wheezy children.

Most studies have found that educational attainment in asthmatic children is about average, though intelligence tends to be somewhat higher. ${ }^{4713}$ None have examined this in relation to school absence. The evidence of the present study suggests that those with more school absence are at an educational disadvantage. This may not be a causal association, however, since most of the socioeconomic and family factors found to be related to school absence may also be associated with educational disadvantage; these include family stress, and mother's mental health.

We thank Dr Margaret Cowan for facilitating the screening survey, Dr Sheila Wolfendale for advising on the educational and psychological assessments, and Dr Martin Bland for statistical advice. Financial support was received from the South West Thames Regional Health Authority.

\section{References}

1 Gregg IA. Epidemiology. In: Clark TJH, Godfrey S, eds. Asthma. London: Chapman and Hall, 1977:214-40.

2 Court SDM, chairman. Fit for the future. Report of the Committee on Child Health Services. London: HMSO, 1976.

3 Pilling D. The child with asthma; social, emotional and educational adjustment; an annotated bibliography. National Children's Bureau. Windsor: NFER Publishing Company, 1975.

4 Graham PJ, Rutter ML, Yule W, Pless IB. Childhood asthma. A psychosomatic disorder? Some epidemiological considerations. Br J Prev Soc Med 1967;21: 78-85.

5 Mitchell RG, Dawson B. Educational and social characteristics of children with asthma. Arch Dis Child 1973; 48:467-71. 
- McNichol KN, Williams HE, Allan J, McAndrew I. Spectrum of asthma in children-III psychological and social components. $\mathrm{Br}$ Med J 1973;4:16-20.

7 Peckham C, Butler N. A national study of asthma in childhood. J Epidemiol Community Health 1978;32:79-85.

8 Anderson HR, Bailey P, West S. Trends in the hospital care of acute childhood asthma 1970-8: a regional study. Br Med J 1980;281:1191-4.

9 Gregg IA. The role of the family doctor in management. In: Clark TJH, Godfrey S, eds. Asthma. London: Chapman and Hall, 1977: 395-400.

10 Bishop YMM. Full contingency tables, logits and split contingency tables. Biometrics 1969;25:383-98.

11 Scadding JS. Definition and clinical categories of asthma. In: Clark TJH, Godfrey S, eds. Asthma. London: Chapman and Hall, 1977: 1-10.

12 Wood PHN, Badley EM. An epidemiological appraisal of disablement. In: Bennett $\mathrm{AE}$, ed. Recent advances in community medicine I. London and Edinburgh: Churchill Livingstone, 1978: 149-73.
13 Dawson B, Horobin G, Illsley R, Mitchell R. Survey of childhood asthma in Aberdeen. Lancet $1969 ; \mathbf{i}: 827-30$.

14 Fox J, Goldblatt P. Socio-demographic differences in mortality. Population Trends 1982;27:8-13.

15 Anderson HR, Bailey PA, Cooper JS, Palmer JC. Influence of morbidity, illness label, and social, family and health service factors on drug treatment of childhood asthma. Lancet 1981 ;ii :1030-2.

16 Davis JB. Neurotic illness in the families of children with asthma and wheezy bronchitis: a general practice population study. Psychol Med 1977;7:305-10.

Correspondence to $\mathrm{Dr} \mathbf{H} \mathbf{R}$ Anderson, Department of Clinical Epidemiology and Social Medicine, St George's Hospital Medical School, Cranmer Terrace, London SW17 0RE.

Received 20 June 1983

British Paediatric Association

Annual meetings

1984 10-14 April York University

1985 16-20 April York University

1986 15-19 April York University

1987 7-11 April York University 